information is available, for example, whether it is the progeny of a particular bull. From the point of view of the Council the objective is to obtain data which will be of value in the study of the genetics of cattle. The preliminary organization, equipping of laboratories, and particularly the training of staff, will take some time, and it will not be possible for samples to be received for test for at least a year. The establishment of the service is being facilitated by the action of certain bodies which have guaranteed their support, and priority will be given in the first instance to samples sent in under the auspices of these bodies. When the service is in a position to accept samples, a further announcement giving details of the service will be made.

\section{Political and Economic Planning}

THE annual report of Political and Economic Planning for the yoar ended March 31, 1963, reports briefly on the six projects in the current research programme started in the two previous years and due for completion by 1964 (Pp. 20. London: Political and Economic Planning, 1963). That dealing with community mental health services has concentrated on comparative field studies in four areas where such services are well developed, and in each area a statistical survey, an interview survey of psychiatric patients living at home and of members of their families has been in progress, as well as a survey of mental health work. In that concerned with prisoners and their families, the field-work on the national sample has been completed and a more intensive study commenced of the families of up to 100 prisoners living in the London area. The enquiry into education and training programmes for doveloping areas is fully under way, and that on Trade Unions in a changing society is due for completion in autumn 1963. The two-year project on attitudes in British industry was startod in April 1962, and the main publication during the year of tho programme on Britain and European integration was Atlantic Tariffs and Trade.

\section{Directory of European Dental Research Workers}

The Commission on Dental Research of the Fédération Dentaire Internationale is in the course of compiling a Directory of European Dental Research Workers. The Commission will be corresponding direct with all dental schools in the United Kingdom requesting information on research personnel. In addition, however, it is desired to include particulars of research workers who are not necessarily dentally qualified and not necessarily working in dental institutions, but who are engaged on studios directly pertaining to dental science. Information concerning institutions where such workers are based should be sent to the Commission on Dental Research, Fédération Dentaire Internationale, 35 Devonshire Place, London, W.1.

\section{Literature in Nuclear Sciences}

Publications in the Nuclear Sciences, 1963, is a complete catalogue of 100 pages of the publications of the International Atomic Energy Agency, and is the fifth edition in the series of catalogues, superseding all previous issues and supploments. The titles are listed in inverse order of publication, that is, with the most recont first, under nine general subject headings: biology, medicine and agriculturo; hoalth, safety and waste disposal; physics, plasma physics and electronics; chemistry, geology and raw materials; reactor physics and reactors; industrial applications; oconomies; law; and miscellaneous and documentation. The publications mostly fall into the following groups or series: "The Proceedings Series", being the proceedings of conferences, symposia and seminars under the ægis of the Agency, which are published in their original language together with abstracts in English, French, Russian and Spanish; "The Safoty
Series", reports on health and safety topics, available in separate English, French, Russian and Spanish versions; "Technical Directories", in English only; "The Technical Report Series", reports on research, mostly in English: "The Bibliographical Series", surveys of world's literature on subjects in the field of nuclear science; and "The Review Series", a completed series of 27 reviews in various languages. Subsequent reviews are now published in the new journal, Atomic Energy Review, which appears at irregular intervals. Nuclear Fusion, a quarterly journal on plasma physics and thermonuclear fusion, is the other four-language journal, distributed on a subscription basis from Vienna and published by the Agency.

\section{Announcements}

Entries for the 1964 Maccabæan Prize and Medal are now invited for an essay of 5,000-7,000 words on some aspect of the history of medicine or pharmacy. Intending candidates, who must be less than thirty years of age on March 15, 1964, can obtain further particulars from the honorary secrotary of the Faculty, Dr. F. N. L. Poynter, Wellcome Historical Medical Library, the Wellcome Building, Euston Road, London, N.W.1.

OCEANOGRAPHERS and meteorologists will be interested to know that the well-known 1905 paper by V. W. Ekman, "On the Influence of the Earth's Rotation on Oceancurrents", has been reprinted. Copies are obtainable from the Royal Swedish Academy of Sciences, Stockholm 50, price 3.50 dollars.

THE fourteenth international Astronautical Congress, arranged this year by the French Astronautical Society, will be held in Paris during September 25-October 1. Further information can be obtained from the Société Française d'Astronautique, 6 rue Galilée, Paris $16^{\mathrm{c}}$.

A ONE-DAY meeting will be held by the British Biophysical Society at the School of Pharmacy, University of London, on September 30. Further information can be obtained from Prof. R. E. Burge, Physics Department, Quoon Elizaboth College, Campden Hill Road, London, W.8.

A symposium on "Light Fading and Colour Assess. ment" will be held by the Society of Dyers and Colourists at St. Anne's on the Sea, Lancashire, during September 11-13. Further information can be obtained from the Society of Dyors and Colourists, P.O. Box No. 244, Dean House, 19 Piccadilly, Bradford I, Yorks.

A symposium on "Transport and Traffic Noise", organized by the Society of Acoustic Teehnology and the Institute of Sound and Vibration Research, will be held at the University of Southampton during September 27-28. Further information can be obtained from Dr. G. M. L. Gladwell, Institute of Sound and Vibration Research, the University, Southampton.

THE Fifth International Soawood Symposium and associated meeting of the International Phycological Society will be held in Halifax, Nova Scotia, during August 25-28, 1965, at Dalhousio University. This meeting has been postponed from 1964 to 1965 due to conflict with othor international conferences. Further information can be obtained from the chairman of the local committee, Dr. E. Gordon Young, National Research Council Laboratory, Halifax, Canada.

AN international symposium on the "Thermal Stability of Polymers", sponsored by the Battelle Memorial Institute, Columbus, Ohio, will be held during December 5-6. It will include papers on both pyrolytic and thermal oxidative stabilities of polymerie structures. In addition, papers will be presented on methods for studying thermal stabilitios and on stabilizing various types of polymers. Further information can be obtained from Dr. Palmer B. Stickney, Battelle Memorial Institute, 505 King Avenue, Columbus 1, Ohio. 